\title{
Juniperus Virginiana Oil
}

National Cancer Institute

\section{Source}

National Cancer Institute. Juniperus Virginiana Oil. NCI Thesaurus. Code C72190.

The oil extracted from the wood of Juniperus virg iniana. Red cedarwood oil is used as an insect repellant, expectorant, antiseptic, and fungicide. 